\title{
65th Birthday of Professor Nobuo Tanaka
}

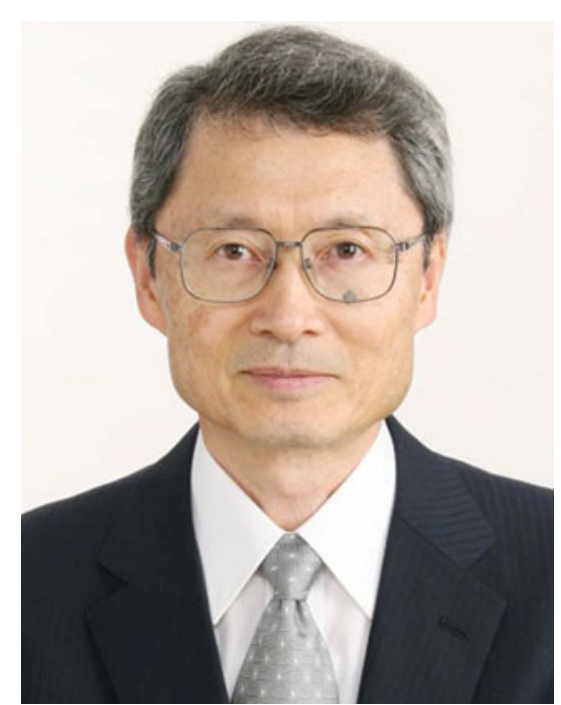

Professor Nobuo Tanaka celebrated his 60 th birthday on the 30th November 2005, when a full account of his work was published in Chromatographia [1]. Since then the intervening 5 years has become one of his most fruitful periods in terms of the outcome. According to the rules of Kyoto Institute of Technology (KIT) he retired from the Institute, on 31 March 2009 when he was 63. He was awarded Professor Emeritus by KIT and joined GL Sciences Inc., Iruma, Saitama near Tokyo to continue research on separation science. He also kept a part-time position in KIT to supervise some students.
Professor Tanaka's researches have been focused on the development and characterization of high-performance columns and stationary phases for HPLC. Recently he has concentrated his efforts on the development of ultra-high efficiency columns based on monolithic silica gel and was successful in realizing $1,000,000$ theoretical plates even for retained solutes with long monolithic silica capillary columns [2]. This technique is a milestone of his research and he must be happy in the great potential this represents for separation science. In the past he has been successful in separating hydrogen, nitrogen, and oxygen isotopic compounds by HPLC by using a recycle column system when necessary but a single long monolithic silica capillary can separate these isotopic compounds without an ultra-high pressure pump, unequivocally proving their separation efficiency. Another advantage of these columns is potentially the high peak capacity required in the separation of extremely complex mixtures such as peptide mixtures of digested proteins [3].

Professor Tanaka received the M.J.E. Golay Award in 2007, the American Chemical Society Award in Chromatography in 2009, and the Prize for Science and Technology from The Minister of Education, Culture, Sports, Science and Technology in 2010. He has published more than 30 papers, review articles, and book chapters in the last 5 years. He serves as an editor, editorial board or advisory board member of several international journals and is a permanent scientific committee member of the HPLC series meetings. He organized HPLC 2008, Kyoto, with Professor Koji Otsuka.

I congratulate him, on behalf of his friends and colleagues, on his 65th birthday and wish him good health, continued success in research, and time to spend with his lovely wife Sachiko in travelling worldwide.

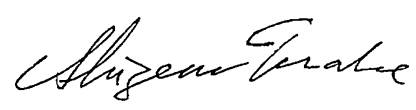

Shigeru Terabe

\section{References}

1. Chromatographia (2005) 62:455-456. doi: 10.1365/s10337-005-0652-2

2. Miyamoto $\mathrm{K}$, Hara $\mathrm{T}$, Kobayashi $\mathrm{H}$, Morisaka H, Tokuda D, Horie K, Koduki $\mathrm{K}$, Makino S, Núñez O, Yang C, Kawabe $\mathrm{T}$, Ikegami $\mathrm{T}$, Takubo $\mathrm{H}$, Ishihama $\mathrm{Y}$, Tanaka N (2008) Anal Chem 80:8741-8750. doi:10.1021/ac801042c

3. Iwasaki M, Miwa S, Ikegami T, Tomita M, Tanaka N, Ishihama Y (2010) Anal Chem 82:2616-2620. doi:10.1021/ac100343q 